\title{
PENDEKATAN PENDIDIKAN KARAKTER BERBASIS DIGITAL BAGI SISWA SEKOLAH DASAR
}

\author{
Akhwani $^{1}$, Tri Deviana Wulansari ${ }^{2}$ \\ ${ }^{1,2}$ Universitas Nahdlatul Ulama Surabaya \\ 1akhwani@unusa.ac.id 2tridevi@unusa.ac.id
}

\begin{abstract}
The development of technology in the $21^{15 t}$ century is a necessity that cannot be avoided. This study aims to examine the approach taken by schools in instilling digital-based character education in elementary schools. The study used a descriptive qualitative design. Data collection was obtained from the results of interviews, observations and documentation. The data analysis technique uses data triangulation to ensure the validity of the data. The results of the study show that there are three approaches taken by schools to instill digital-based character education in elementary schools. These approaches are; approach to teaching and learning activities (KBM), the approach carried out in the classroom; approaches in the school environment and school culture; and student approaches outside the school environment. Each approach has a varied program of activities. The approach to teaching and learning activities is carried out more than other activities. The program of activities is carried out through restrictions on the use of gadgets, wise digital access and digital literacy.
\end{abstract}

Keywords: character education; digital; elementary school

\begin{abstract}
Abstrak
Perkembangan teknologi di abad ke-21 merupakan sebuah keniscayaan yang tidak dapat dihindari. Penelitian ini bertujuan untuk mengkaji pendekatan yang dilakukan sekolah dalam menanamkan pendidikan karakter berbasis digital di sekolah dasar. Penelitian menggunakan desain kualitatif deskriptif. Pengumpulan data diperoleh dari hasil wawancara, observasi dan dokumentasi. Teknik analisis data menggunakan triangulasi data untuk memastikan keabsahan data. Hasil penelitian menunjukan terdapat tiga pendekatan yang dilakukan sekolah untuk menanamkan pendidikan karakter berbasis digital di sekolah dasar. Pendekatan tersebut yakni; pendekatan kegiatan belajar mengajar (KBM), pendekatan yang dilakukan di ruang kelas; pendekatan di lingkungan sekolah dan budaya sekolah; dan pendekatan siswa di luar lingkungan sekolah. Masing-masing pendekatan memiliki berbagai program kegiatan yang variatif. Pendekatan kegiatan belajar mengajar lebih banyak dilakukan dibandingkan kegiatan yang lain. Program kegiatan dilakukan melalui pembatasan penggunanan gawai, akses digital secara bijak dan literasi digital.
\end{abstract}

Kata Kunci: digital; pendidikan karakter; sekolah dasar

\begin{tabular}{llll}
\hline Received & $: 2020-12-30$ & Approved & $: 2021-06-09$ \\
Reviesed & $: 2021-06-07$ & Published & $: 2021-07-31$ \\
\hline
\end{tabular}

(c) () (?) Jurnal Cakrawala Pendas is licensed under a Creative Commons Attribution-

\section{Pendahuluan}

Era digital menjadi sebuah keniscayaan yang tidak dapat dihindari lagi. Perkembangan teknologi dan komunikasi menjadi bukti nyata perubahan di era digital (Haryanti \& Saputra, 2019). Mulai dari anak-anak sampai dewasa memiliki perangkat digital seperti smartphone dan tablet. Mereka disibukan dengan perangkat digital dalam setiap aktivitasnya. Terlebih bagi anak-anak, gawai seolah tidak pernah lepas dari jangkauannya. Tidak jarang anak usia sekolah dasar sudah memiliki gawai. Sudah jarang ditemukan mereka bermain gundu, petak umpet atau permainan tradisional. Mereka lebih tertarik bermain gawai. 
Anak-anak yang saat ini duduk di bangku SD merupakan digital natives yang lahir dan berkembang di era digital (Drakopoulou et al., 2016). Sebagai digital natives, menavigasi internet dan menggunakan sosial media adalah aktivitas sehari-hari. Mereka sangat nyaman dengan fasilitas yang tersedia di gawainya. Parahnya, mereka tidak menyadari aturan dan normanorma di dunia digital (Young, 2014). Tidak ada yang bisa menjamin bahwa anak yang memiliki kecakapan digital juga memiliki etiket digital.

Siswa SD saat ini dapat dikatakan "kecanduan" dengan gawai dan internet. Banyak diantara mereka sudah memiliki akun media sosial seperti Facebook, Intagram, Whatsapp. Mereka juga menggunakan beragam aplikasi seperti Tik Tok, Dubsmash, Vigo, Snapchat serta aplikasi lainnya. Sosial media seyogyanya bagi usia dewasa, bukan anak-anak karena mereka belum bisa menggunakan secara bijak. Banyak dampak negatif yang muncul akibat kebiasaan tersebut. Pengguna tidak jarang disuguhkan dengan konten-konten yang tidak layak bagi anakanak usia SD. Anak usia sekolah dasar dengan mudah memposting tulisan atau gambar tanpa mempertimbangkan apakah jejak digitalnya layak atau tidak untuk dibagikan.

Tidak semua konten yang tersedia di internet layak bagi anak-anak (Akhwani \& Djazilan, 2018). Orang tua sebagai digital immigrant hanya bisa membatasi tanpa bisa memantau aktivitas yang dilakukan anak dengan gawainya. (UNESCO, 2015) mencatat 70 persen dari anak Indonesia yang disurvei menambahkan orang tidak dikenal menjadi temannya di media sosial dan 35 persen diantaranya meminta untuk bertemu secara pribadi. Hal ini tentu akan sangat berbahaya bagi anak-anak. Hasil penelitian (McGillivray et al., 2015) juga menyebutkan bahwa kemajuan teknologi memunculkan permasalah jenis baru yang belum pernah terjadi sebelumnya.

Pendidikan di sekolah memiliki peran penting untuk mengatasi permasalahan di era digital. Siswa SD penting untuk mendapatkan bekal norma dan sopan santun dalam menavigasi internet. Bekal tersebut dinamakan etiket digital. Pendidikan karakter berbasis digital bukanlah topik yang terpisah dalam kurikulum sekolah, justru membentang di semua bidang pendidikan. Zaman telah berubah, cara mendidik anak juga harus disesuaikan dengan zamannya. Perlu adanya keterlibatan dari berbagai pihak dalam menyongsong kemajuan generasi masa depan (Akhwani \& Wahyudi, 2020; Nahdi \& Jatisunda, 2020)

Siswa SD harus mendapatkan bekal dasar yang kuat sebelum terjun dalam dunia digital. Pendidikan karakter berbasis digital mutlak diberikan sebagai penyeimbang antara pengetahuan dan sikap anak. Permasalahan di era digital akan muncul kapanpun dan di manapun. Membekali anak sejak dini merupakan langkah awal mempersiapkan generasi masa depan yang memiliki norma dan etika dalam menavigasi internet.

Sekolah Dasar memiliki peran penting untuk mendidik siswanya supaya memiliki etika baik di dunia nayata maupun di dunia maya. Implementasi Pendidikan karakter harus menyentuh ranah digital. Tidak ada yang dapat menjamin ada keselarasan antara etika di dunia nayata dan dunia maya (Akhwani, 2019). Di dunia nyata perilaku anak dapat diamati dengan jelas. Namun di dunia maya pengamatan itu akan sulit diukur. Di dunia maya tidak mudah mengenal identitas seseorang. Terlebih lagi di dunia maya anak dapat bertindak bebas tanpa ada aturan baku yang memandunya.

Tujuan Pendidikan yang telah diamanahkan dalam Undang-undang Sisdiknas Nomor 20 tahun 2003 seyogyanya dimaknai secara luas. Pendidikan di sekolah memiliki tanggung jawab mempersiakan siswa yang berakhlak mulia (Undang-undang 20, 2003). Untuk mewujudkan tujuan pendidikan tersebut, perlu adanya upaya dan strategi yang tepat. Tidak mungkin anak berkarakter secara tiba-tiba tanpa ada pengaruh dari luar. Strategi pendidikan 
karakter di era digital menjadi penting untuk diimplementasikan. Tidak hanya pada tataran teori tetapi juga lebih pada tataran praktik kehidupan sehari-hari.

Hasil penelitian Triyanto (2020) menyebutkan bahwa Era digital memberikan ruang positif sebagai sarana pendidikan karakter. Pembelajaran karakter mampu mempromosikan pengembangan keterampilan abad ke-21. Pendidikan karakter seyogyanya tidak hanya sekedar dipromosikan melainkan misi yang harus diwujudkan dalam tindakan. Keberhasilan pendidikan karakter berbasis digital membutuhkan peran orang tua siswa dan lingkungan rumah sebagai mitra sekolah (Santika, 2020).

Pendidikan karakter berbasis digital merupakan sebuah ikhtiar untuk mewujudkan citacita tujuan Pendidikan nasional. Artinya tidak ada yang dapat memastikan bahwa sekolah yang menerapkan akan berhasil dan setiap anak memiliki etiket digital yang unggul daripada anak yang tidak mengikuti program etiket digial. Namun setidaknya ada upaya sekolah untuk memberikan fasilitas yang terbaik bagi anak bangsa sebagai generasi penerus masa depan.

Hasil penelitian terkait program pendidikan karakter berbasis digital yang dilakukan di Sekolah Dasar di Amerika nampak memberikan pengaruh postif bagi siswa (Young, 2014). hasil penelitian tentang penyelenggaraan pendidikan karakter berbasis digital di sekolah dasar menyebutkan bahwa siswa sekolah dasar menyadari bahwa tindakan yang dilakukan di internet sebelumnya adalah salah. Mereka tidak mengetahui bagaimana menavigasi internet dengan tepat sebelum adanya pendidikan digital citizenship. Mereka juga berjanji untuk lebih bijak dalam mengambil keputusan dan bertindak.

Hasil penelitian pendidikan karakter berbasis digital pada jenjang SMA menyebutkan bahwa pendekatan dilakukan melalui visi-misi, pembelajaran di dalam kelas dan programprogram sekolah (Mumtahanah \& Suyuthi, 2020). Penelitian pendidikan karakter bagi siswa di sekolah dasar menyebutkan bahwa peran keluarga, guru dan masyarakat sekitar sangat penting untuk mempersiapkan generasi masa depan. Anak usia sekolah dasar telah mengenal gaya hidup digital baik dari rumah, teman, sekolah dan lingkungan sekitar (Putri et al., 2021). Sementara, Penelitian pendidikan karakter di era digital pada jenjang perguruan tinggi menyebutkan bahwa kegiatan dilakukan melalui berbagai kegiatan seminar, FGD dan kelas kebangsaan (Armaidy Armawi, 2020).

Beberapa hasil penelitian di atas memberikan gambaran implementasi dan program yang dilakukan dari berbagai jenjang. Nampak bahwa kondisi ruang lingkup pendidikan karakter di era digital sangat luas, belum diketahui pola pendekatan secara spesifik. Penelitian yang fokus mengungkap pola pendekatan pendidikan katakter yang spesifik pada jenjang sekolah dasar perlu dilakukan. Tujuan dari penelitian ini adalah untuk mencari pola pendekatakan pendidikan karakter di era digital di sekolah dasar. Fokus sekolah dasar menjadi penting karena mereka sudah mengenal gaya hidup digital. Pola pendidikan karakter di era digital mempermudah mongkategorikan bentuk pendidikan karakter.

\section{Metode Penelitian}

Penelitian ini merupakan penelitian kualitatif. Fakta di lapangan akan memandu peneliti untuk menemukan suatu hasil yang akan dirangkai menjadi sebuah simpulan. Pendekatan kualitatif deskriptif digunakan untuk mendeskripsikan fenomena yang ditemukan di lapangan. Penelitian mencoba mengungkap strategi-strategi penguatan etiket digital yang diselenggarakan di sekolah dasar. Penelitian penguatan etiket digital dilakukan di Sekolah Dasar di Kota Surabaya. 
Pengumpulan data dilakukan dengan observasi, wawancara dan dokumentasi. Observasi dilakukan selama penelitian dengan mengamati secara langsung fenomena di lokasi penelitian. Wawancara menjadi hal penting dalam pelaksanaan ini, karena interviewer akan mendapatkan informasi dari hasil wawancara pihak terkait. Selain itu, dokumentasi juga menjadi pelengkap dan data pendukung untuk menguatkan hasil wawancara dan observasi.

Data dianalisis dengan membandingkan data hasil observasi yang dilakukan oleh interviewer dengan hasil wawancara dari sumber informan. Selain itu interviewer juga membandingkan apa yang disampaikan oleh informan satu dengan informan lain untuk memperkuat informasi. Untuk mengecek kebenaran hasil wawancara juga dibandingkan dengan isi suatu dokumen yang terkait. Data dari sekolah-sekolah yang menjadi lokasi penelitian dikumpulkan kemudian direduksi untuk ditajamkan digolongkan antara data yang diperlukan dan data pendukung yang dirasa kurang perlu. Data-data penelitian juga disajikan dengan disusun menjadi sebuah laporan penguatan etiket digital di sekolah SD, data juga diredusi terkait strategi-strategi apa yang telah dilakukan. Pada tahap yang terakhir yakni penarikan kesimpulan untuk dari hasil data yang telah dikumpulkan.

\section{Hasil dan Pembahasan}

Langkah awal yang dilakukan sekolah pada dasarnya adalah mempersiapkan sumber daya manusia yang tanggap dengan era digital. Sekolah menuntut warga sekolah untuk kreatif menyikapi perkembangan zaman. Penting bagi guru untuk memiliki literasi digital. Jangan sampai terjadi ketidakseimbangan antara kacakapan digital guru dengan siswa. Seyogyanya literasi digital guru lebih unggul dari pada siswanya. Akan sangat aneh jika sekolah merancangan program etiket digital sementara gurunya lemah dalam literasi digital.

Selain dari sisi sumber daya manusia, sarana dan prasarana merupakan indikator yang mendukung terwujudnya siswa yang memiliki etiket digital. Sekolah-sekolah dasar sudah mempersiapkan laboratorium komputer untuk mendekatkan anak dengan era digital. Laboratorium berfungsi untuk mengembangkan kemampuan dasar anak agar berkembang secara positif. Pembelajaran di ruang kelas juga sudah di arahkan menggunakan LCD, Projektor yang akan mendukung tercapainya tujuan pembelajaran. Akses internet juga tersedia di sekolah untuk menunjang penyelenggaraan sekolah di era digital.

Sekolah telah sadar betul manfaat dan pengaruh teknologi digital bagi masa depan anak. Di beberapa sekolah telah mengimplementasikan pembelajaran berbasis digital meskipun masih terbatas di kelas tinggi, yakni kelas empat, lima dan enam. Sekolah mulai mengarahkan pada ujian berbasis digital. Siswa mengerjakan soal ujian dengan menggunakan gawai. Dengan demikian selain mengajarkan kecakapan digital juga memberikan kebiasaan penggunaan gawai untuk kegiatan yang bermanfaat.

Implementasi penguatan karakter berbasis digital di sekolah menjadi tanggung jawab bersama warga sekolah. Semua pihak terlibat untuk mensukseskan sekolah yang ramah digital. Etika atau norma pada dasarnya memang masuk pada ranah Pendidikan Kewarganegaraan dan Pendidikan Agama, namun dalam membentuk etika digital. guru TIK turut terlibat memberikan arahan penggunaan teknologi digital yang aman dan bertanggung jawab bagi siswa. Sekolah pada dasarnya tidak memiliki nomenklatur pendidikan karakter berbasis digital. Program ini menyatu beriringan dengan program yang terlaksana di sekolah. Sekolah-sekolah pada umumnya mengimplementasikan program etiket digital dengan terintegrasi dengan program-program lainnya. Meskipun demikian, nilai-nilai dan etika dalam menavigasi internet tidak ditinggalkan. Sekolah dapat menyelipkan program pendidikan karakter berbassis digital 
melalui program-program sekolah, ekstrakurikuler computer, program full day school, aplikasi belajar online.

Setiap sekolah pada dasarnya memiliki pendekatan yang berbeda dalam menanggapi era digital. Sekolah satu dengan sekolah yang lain memiliki program yang tidak sama sesuai kebutuhan sekolah. Bahkan ada beberapa kebijakan sekolah yang berbeda dalam menyikapi kebutuhan siswa di era digital. Kondisi ini tentu sangat wajar mengingat kebutuhan siswa pada masing-masing sekolah tidak sama, sakalipun tujuan yang dicapai sama, yakni membentuk siswa yang memiliki karakter di era digital.

Secara garis besar ada tiga pendekatan yang dilakukan sekolah-sekolah dasar dalam menyelenggarakan pendidikan karakter berbasis digital sekolah dasar. Pendekatan ini diambil setelah ditemukan program-program yang sejenis berdasarkan ruang lingkupnya. Tiga pendekatan tersebut terbingkai dalam penguatan etiket digital melalui kegiatan belajar mengajar; penguatan etiket digital di lingkungan sekolah; penguatan etiket digital di luar sekolah.

Tiga bingkai tersebut merupakan wadah strategi penguatan karakter berbasis digital di sekolah dasar. Pada masing-masing bingkai pendekatan memuat program yang diimplementasikan pada masing-masing sekolah. Pertama, pada bingkai kegiatan belajar mengajar. Pendekatan ini terdiri dari program literasi digital dan program seminar atau sosialisasi. Pada kegiatan literasi digital, sekolah memiliki peran untuk memastikan kecakapan digital bagi semua warga sekolah. Artinya sasaran dari program ini tidak terbatas pada siswa saja. Sementara pada program seminar atau sosialisasi sekolah mengadakan sosialisasi terkait etika menavigasi internet kepada siswa maupun orang tua.

Bingkai yang kedua yakni kegiatan di lingkungan sekolah. Terdapat tiga program yang dapat dilakukan sekolah. Program tersebut dilakukan dengan memantau siswa selama di lingkungan sekolah; melakukan pembatasan penggunaan gawai; dan membentuk sekolah yang ramah digital. Memantau siswa artinya memantau aktivitas siswa dalam menggunaka gawai di lingkungan sekolah. Sementara pembatasan penggunaan gawai maksudnya sekolah membatasi siswa dalam menggunakan gawai selama di lingkungan sekolah; berikutnya yakni menciptakan sekolah dengan suasana yang ramah dan nyaman dalam menavigasi internet.

Pendekatan yang terakhir yaitu pendekatan di luar lingkungan sekolah. Sekolah melakukan sinergi dengan wali murid untuk mensukseskan tujuan yang ingin dicapai dalam hal apapun. Sinergi dalam menguatkan etiket digital ini dilakukan dengan bekerjasama antara sekolah dengan orang tua dalam memantau anaknya di rumah. Di sekolah anak cenderung terbatas menggunakan gawai tapi di rumah, anak cenderung mudah menggunakannya. Melalui sinergi program sekolah dan orang tua dapat saling berkomunikasi terkait anaknya. Sinergi ini dapat dilakukan melalui whatsapp grup (WAG) atau sejenisnya.

\section{Urgensi Etiket Digital Siswa di Sekolah Dasar}

Sekolah memiliki peran penting dalam memberikan pendidikan dan penggunaan perangkat digital secara tepat bagi siswa (Ribble, 2012) (Ribble \& Bailey, 2007). Sekolah perlu menyadari bahwa penggunaan perangkat digital telah menyentuh di bidang pendidikan. Gawai hanyalah sebuah perangkat. Gawai dapat digunakan sebagai media pendukung tercapainya pembelajaran, tetapi di sisi lain juga dapat menjadi "bumerang" jika tidak dioperasionalkan secara tepat. Sekolah perlu mengambil alih dan menindaklanjuti fenomena tersebut. Siswa perlu mendapatkan layanan bagaimana menggunakan perangkat digital secara baik dan benar.

Siswa SD di era digital mampu mengoperasionalkan perangkat digital, namun banyak diantaranya yang tidak memahami penggunaan gawai secara bijak, terlebih lagi jika sudah 
dihubungkan dengan hukum privasi, hak akses dan penggunaan informasi (Jones \& Mitchell, 2015). Sekolah memiliki posisi yang strategis dalam mengembangkan etiket digital siswa. Terlebih lagi di Sekolah Dasar yang siswanya belum banyak mengetahui etiket digital. Upayaupaya pencegahan dan pemberdayaan sangat penting dilakukan dalam membentuk lingkungan digital yang aman dan nyaman

Usia sekolah dasar merupakan usia yang paling mudah untuk menerima informasi. Sasaran pengembangan etiket digital sangat tepat apabila diberikan sejak dini. Siswa SD akan mendapatkan dasar pengambilan keputusan yang baik dalam menavigasi internet. Terlebih lagi anak-anak SD saat ini yang sudah memiliki akun media sosial. Dengan adanya etiket digital diharapkan mereka mampu menavigasi internet dengan bertanggung jawab. Peran sekolah sangat strategis mengingat orang tua tidak cukup mampu membatasi dan mengawasi apa yang dilakukan anaknya ketika menavigasi internet.

Implementasi pendidikan karakter berbasis digital penting untuk diterapkan di sekolah (Choi, 2016), (Rye, 2013), (Isman \& Gungoren, 2014). Anak-anak usia sekolah sekolah dasar sangat akrab dengan gawai di era digital. Mulai bangun tidur sampai mau tidur lagi gawai tidak pernah lepas dari jangkauan anak. Bukan tidak mungkin ada kegiatan anak yang tidak tepat selama mengoperasionalkan gawai. Kecanduan gawai seolah merata di setiap anak di era digital.

Dalam sudut pandang kewarganegaraan, mengajarkan pendidikan karakter berbasis digital kepada anak usia sekolah sama dengan mengajarkan menjadi warga negara yang baik. Artinya sekolah memiliki peran dalam mempersiapkan generasi masda depan. Di era digital mempromosikan penggunaan intenet yang aman menjadi sebuah langkah yang tepat. Anakanak usia sekolah hanya mengetahui hidup dengan koneksi internet yang instan, mudah berhubungan dengan siapapun tanpa mengetahui bagaimana tanggung jawab yang ada di dalamnya (Jones \& Mitchell, 2015)

Bergulirnya revolusi industri 4.0 yang diiringi dengan teknologi digital membuat sejumlah tokoh pendidikan memberikan rekomendasi. Pada abad ke-21 kecakapan dalam menggunakan teknologi digital di sekolah harus meningkat (Trilling \& Fadel, 2009). Selain itu akses informasi seyogyanya dilakukan secara aktif dan efisien. Perlu adanya keseimbangan antara literasi digital dengan etiket digital. Dua hal yang tidak boleh ditinggalkan dalam kerangka Pendidikan di abad ke-21. Bahkan beitu pentingnya penguasaan. (Bennett et al., 2009) menyarankan agar ada perubahan kurikulum yang mampu mengakomodir kedua hal tersebut.

Redesain kurikulum memang dibutuhkan di era digital. Kecakapan dan tuntutan di abad ke-21 membawa pada pola bentuk Pendidikan yang mengarah pada penggunakan gawai dan internet sebagai nyawa. Jiika sekolah tidak menyikapi kondisi ini dengan bijak, bukan tidak mungkin akan permasalahan baru di era digital akan muncul. Meskipun demikian sekolah juga mampu mengantisipasi dan memiliki otonomi untuk menyusun program sesuai dengan kebutuhan sekolah. Pembelajaran diintegrasikan dengan teknologi sebagai bagian dari tuntutan abad ke-21 (Asyiah \& Sati, 2020).

Alasan penting siswa memiliki norma dan tanggung jawab dalam menavigasi internet antara lain; Banyak anak sekolah menghabiskan waktu dengan internet; penting bagi siswa untuk menyadari dampak jangka panjang penggunaan internet; di era digital akses internet sangat mudah didapatkan; selain itu tuntutan di abad ke-21 semua siswa harus memiliki kecakapan digital dan yang terakhir adalah banyaknya kasus-kasus jenis baru yang muncul setelah ada internet (Ribble, 2012).

Alasan tersebut sangatlah masuk akal. Alasan tersebut telah terbukti dan terasa dalam kehidupan masyarakat. Implementasi etiket digital di sekolah adalah langkah yang tepat untuk 
membentuk suasana digital menjadi lebih baik. Permasalahan baru yang ditimbulkan dari internet akan terus bermunculan. Untuk menghentikan dan mengantisipasi hal tersebut mempersiapkan anak sejak dini melalui dunia pendididikan adalah sebuah urgensi. Melalui dunia Pendidikan setiap anak akan terbentuk etika baik di dunia nyata maupun di dinia maya.

\section{Strategi Pendidikan Karakter berbasis Digital di Sekolah Dasar}

Menanamkan karakter kepada siswa tidak semudah mengajarkan pengetahuan. Menumbuhkembangkan etika butuh strategi dan waktu yang tidak sebentar. Keberhasilan di satu tempat belum tentu berhasil diterapkan ditempat lain. Sekolah tentu memiliki strategi atau metode tersendiri dalam mengembangkan etiket digital bagi siswa di sekolahnya. Sekolah tentu tidak ingin peserta didiknya dikemudian hari bermasalah karena etika digitalnya.

Strategi penguatan pendidikan karakter berbasis digital di sekolah sebenarnya bagian dari sembilan elemen Digital Citizenship. Sembilan elemen tersebut adalah akses digital, komunikasi digital, kecakapan digital, perlindungan digital, etiket digital, hak dan tanggung jawab digital, hukum digital, kesehatan digital dan perdagangan digital. tujuan yang ingin dibangun dari Digital Citizenship adalah dalam rangka mendidik, memberdayakan dan menlindungi pengguna digital (Ribble \& Bailey, 2007)

Sembilan elemen tersebut dianggap berat diterapkan di sekolah karena cakupannya yang cukup luas. Selain itu perlu persiapan yang matang dalam proses implementasinya. Etiket digital menjadi pilihan karena sumber dari perlaku seseorang adalah karakter. Karakter yang baik akan memandu perilaku yang baik pula. Mempersiapkan anak dengan karakter yang baik sama artinya dengan mempersiapkan warga negara yang baik di masa depan.

Sekolah dasar menyadari pentingnya membentuk karakter anak di era digital. Kerangka program yang dilakukan sekolah jika dikelompokkan terbagi menjadi tiga ruang. Ketiga ruang tersebut meliputi kegiatan belajar mengajar di dalam kelas; kemudian program yang berada di luar kelas atau di lingkungan sekolah dan yang terakhir program yang berada di luar lungkungan sekolah. Strategi sekolah yang pertama yaitu pada ruang lingkup kegiatan belajar mengajar di kelas. Strategi penguatan yang dilakukan bersama dengan pembelajaran yang dilakukan antara pendidik dengan siswa. Implementasinya sesuai dengan kebutuhan dan program sekolah. Sekolah tidak menyediakan jadwal khusus dalam setiap bulan atau setiap semesternya. Pendidikan etiket digital melalui kegiatan belajar mengajar lebih lebih pada hidden curriculum. Sekolah tidak memberikan dalam satu mata pelajaran atau dalam satu bab khusus.

Ada dua strategi yang dapat diimplementasikan di sekolah dalam kegiatan belajar mengajar di sekolah, yakni literasi digital dan seminar/sosialisasi etiket digital. Pertama, melalui literasi digial. Sekolah memastikan kecakapan digital bagi semua warga sekolah. Sekolah telah menyadari bahwa zaman telah berubah, maka kompetensi warga sekolah harus berubah pula. Semua warga sekolah, terutama guru dituntut memiliki literasi digital. Guru dituntut untuk kreatif dan inovatif dalam mengelola kelas dengan teknologi.

Guru dapat memanfaatkan sumber belajar yang tersedia di internet. Selain itu beragam aplikasi Pendidikan banyak tersedia saat ini. Pemanfaatan aplikasi pendidikan dapat dijadikan guru dalam rangka menambah literasi digital. Siswa mulai diarahkan untuk mencari sumber belajar secara mandiri di internet. Sumber belajar tidak terbatas pada buku saja. Dengan mencari di internet mereka akan belajar dan cenderung tertarik daripada membaca buku cetak. Namun anak perlu mendapat pengawasan dari orang tua atau guru.

Literasi digital guru tidak boleh tertinggal dan tidak menyesuaikan perkembangan zaman. Guru menjadi agen dari literasi digital. Pembejaran dikelas dikelola dengan baik dengan pemanfaatan media digital sebagai sarana pendukungnya. Demikian juga warga sekolah yang 
lain. Program-program sekolah perlu digeser pada pemanfaatan teknologi digital. selain memberikan kemudahan teknologi digital juga memberikan kecepatan sehingga pekerjaan lebih efektif.

Siswa sebagai objek dalam Pendidikan etiket digital pada dasarnya sudah memiliki literasi digital. Mereka perlu mendapatkan bimbingan dari guru maupun dari pihak yang terlibat untuk menjadi Digital natives yang memiliki norma dan etika. Mengembangkan potensi anak pada usia dini dianggap lebih efektif daripada ketika mereka sudah beranjak dewasa. Dengan literasi digital siswa akan mendapatkan bekal menavigasi internet dengan aman dan bertanggung jawab.

Kedua yakni melalui sosialisasi atau seminar. Seminar diselenggarakan dalam rangka memberikan arahan kepada siswa agar sadar dengan adanya era digital. Siswa dibimbing untuk memastikan jejak digital yang ditinggakan selama menavigasi internet adalah aman. Umunya mereka hanya menggunakan tanpa menyadari bahwa tidak semua konten yang ada di internet adalah aman untuk dikonsumsi anak (Nordin et al., 2016). Dengan memberikan arahan lebih awal diharapkan siswa sadar bagaimana peran tanggung jawabnya.

Sosialisasi atau seminar dapat dilakukan dengan melibatkan orang tua atau hanya dari siswa saja. Sosialisasi dapat dipadukan dengan kegitan lain sehingga tidak memerlukan waktu khusus. Sosialisasi juga dapat diberikan di awal penerimaan siswa baru, materi etiket digital dapat disisipkan. Sosialisasi dapat diberikan pada saat penerimaan raport atau hasil belajar. Pada saat itu, wali murid dan guru kelas dapat memberikan sosialisasi dan evaluasi kegiatan siswa selama satu semester.

Strategi kedua yakni di lingkungan sekolah. Ada tiga program yang dapat dijalankan. Pertama, Warga sekolah termasuk guru memantau aktivitas yang dilakukan siswa selama waktu istirahat, waktu pulang atau waktu lain yang di luar pantauan guru kelas. Pemantauan siswa ini banyak sekali manfaatnya bagi sekolah, karena selama siswa di sekolah maka menjadi tanggung jawab sekolah. Terlebih bagi sekolah yang memberikan izin membawa gawai. Dengan demikian semua aktivitas akan terpantau dengan baik.

Sekolah-sekolah yang menyelenggarakan full day school memiliki tanggung jawab yang besar dalam memantau anak di sekolah. Terlebih aktivitas siswa setelah kegiatan belajar mengajar sudah selesai. Di kota-kota besar ditemukan orang tua yang bekerja seharian, dengan demikian pemantauan yang diberikan kepada anak terbatas. Lingkungan sekolah menjadi pilihan untuk mendidik anak daripada anak berada di luar jangkauan anak.

Kedua, yakni pembatasan penggunaan Smartphone. Siswa diperbolehkan atau dilarang membawa gawai merupakan kebijakan sekolah. Semua kebijakan pasti ada kelebihan dan kekurangannya. Langkah yang dapat diambil dalam rangka pendidikan etiket digital di sekolah adalah membatasi penggunnaan gawai. Pembatasan ini bukan berarti menjauhkan siswa dari gawai, tapi memberikan waktu yang tepat dalam menggunakan gawai.

Sekolah memperbolehkan anak membawa gawai umumnya dikarenakan untuk menghubungi orang tua pada saat pulang atau ketika ada kegiatan sekolah. Tetapi jika gawai digunakan di luar kebutuhan itu, seperti bermain tentu tidak tepat. Strategi yang dapat dipilih adalah dengan menitipkan gawai kepada wali kelas. Beberapa sekolah bahkan melarang membawa gawai dengan berbagai pertimbangan. Sekolah biasanya memfasilitasi anak jika ingin menghubungi orang tua atau jika ada kegiatan yang di luar kendali.

Strategi ketiga pada program di luar kelas adalah sekolah yang ramah digital. Sekolah menciptakan suasana yang nyaman bagi anak untuk belajar teknologi dan digital. Sopan dan menghormati orang lain dalam internet merupakan kunci keselamatan di internet(Jones \& Mitchell, 2015). Sekolah memfasilitasi laboratorium komputer untuk mengembangkan potensi 
anak. Kegiatan-kegiatan anak dapat didekatkan dengan pembelajaran digital, misalnya kuis online dari guru, tugas mencari sumber belajar di internet, mengunjungi websiter tertentu, serta memandu keamanan digital.

Strategi penguatan etiket digital yang terakhir adalah sekolah bersinergi dengan orang tua. Strategi ini merupakan program yang ada di luar sekolah. Sekolah bekerja sama dengan orang tua dalam memantau anak melalui WA group atau sejenisnya. Sekolah berinteraksi dengan wali murid terkait kondisi anaknya. Dalam kegiatan belajar mengajar misalnya, guru memberikan tugas untuk mengunjungi website tertentu. Guru dapat memberikan pembertitahuan kepada wali murid supaya dapat dipantau juga aktivitas anaknya. Orang tua juga dapat menaruh kepercayaan kepada anaknya bahwa yang dilakukan dengan gawainya adalah dalam rangka mengerjakan tugas.

Sinergi ini umumnya telah dilakukan sekolah-sekolah, antara wali kelas dengan walimurid. Komunikasi digital menjadi penting karena dalam pandangan (Ribble, 2012) komunikasi digital menjadi bagian yang dari elemen pembentukan digital citizenship. Komunikasi menjadi sarana bertukar informasi antara sekolah dengan wali murid, selain itu aktivitas dan kegiatan yang bersangkautan dengan pribadi anak dapat dikomunikasikan secara langsung tanpa harus bertemu dengan anak.

Prevention is better than cure merupakan ungkapan yang pantas dalam menghadapi era digital. Menyusun program bagi siswa di sekolah dasar menjadi tepat sebelum muncul permasalahan jenis baru di era digital. Pengguna internet penting untuk memiliki kemampuan menggunakan internet yang aman dan bertanggung jawab (McGillivray et al., 2015). Artinya strategi-strategi sekolah untuk mengembangkan potensi anak di era digital menjadi sebuah kebutuhan.

\section{Kesimpulan}

Pendekatan pendidikan karakter berbasis digital merupakan ikhtiar untuk mendidik etika anak di era digital. Pendekatan pendidikan karakter berbasisdigital dilakukan melalui pola kegiatan belajar mengajar di ruang kelas, pola kegiatan yang diselenggarakan di luar kelas dan pola pendekatan di luar kegiatan sekolah seperti partisipasi orang tua dan masyarakat. Pendekatan yang telah disusun merupakan program-program pengalaman yang telah dilakukan sekolah. Masih dimungkinkan adanya program-program lain yang bisa jadi lebih tepat diterapkan di sekolah. Sekolah dapat mengambil program-program yang telah dipaparkan sesuai dengan kebutuhan dan kondisi sekolah.

\section{Daftar Pustaka}

Akhwani, A. (2019). Strategy of Digital Etiquette Education of Elementary School Students. PrimaryEdu - Journal of Primary Education, 3(2), 43. https://doi.org/10.22460/pej.v3i2.1378

Akhwani, \& Djazilan, M. S. (2018). Sosialisasi Urgensi Etiket Digital bagi Santri Zaman Now di Pondok Pesantren Salafiyah Cokrokertopati Kabupaten Magetan. Community Development Journal, 2(1), 93-102.

Akhwani, \& Wahyudi, A. (2020). Ecology and Citizenship; Building Student's Eco Citizenship through Engaging The 'Green Youth' Community Wonosalam Jombang. Education and Human Development Journal, 5(2), 99-118.

Armaidy Armawi. (2020). Reduksi Informasi Hoax di Era Digital Melalui Pendidikan Karakter Berbasis Pancasila. Journal of Chemical Information and Modeling, 15(9), 1689-1699.

Asyiah, N., \& Sati. (2020). Implementasi Strategi 5R untuk Mengoptimalkan Keterampilan Abad 21 Mahasiswa PGSD. Jurnal Cakrawala Pendas, 6(1), 56-62.

Bennett, W. L., Wells, C., \& Rank, A. (2009). Young citizens and civic learning: Two 
paradigms of citizenship in the digital age. Citizenship Studies, 13(2), 105-120. https://doi.org/10.1080/13621020902731116

Choi, M. (2016). A Concept Analysis of Digital Citizenship for Democratic Citizenship Education in the Internet Age. Theory and Research in Social Education, 44(4), 565-607. https://doi.org/10.1080/00933104.2016.1210549

Drakopoulou, S., Grossman, W., \& Moore, P. (2016). The campaign for digital citizenship. Soundings, 62(62), 107-120. https://doi.org/10.3898/136266216818497785

Haryanti, Y. D., \& Saputra, D. S. (2019). Instrumen Penilaian Berpikir Kreatif Pada Pendidikan Abad 21. Jurnal Cakrawala Pendas, 5(2), 58-64. https://doi.org/10.31949/jcp.v5i2.1350

Isman, A., \& Gungoren, O. C. (2014). Digital Citizenship. TOJET: The Turkish Online Journal of Educational Technology, 13(1), 83-96. https://doi.org/10.1057/9780230299047_14

Jones, L. M., \& Mitchell, K. J. (2015). Defining and measuring youth digital citizenship. New Media and Society, 18(9), 2063-2079. https://doi.org/10.1177/1461444815577797

McGillivray, D., McPherson, G., Jones, J., \& McCandlish, A. (2015). Young people, digital media making and critical digital citizenship. Leisure Studies, 35(6), 724-738. https://doi.org/10.1080/02614367.2015.1062041

Mumtahanah, N., \& Suyuthi, A. (2020). Penguatan Pendidikan Karakter Melalui Inovasi Media Pembelajaran Berbasis Digital di MAN 1 Lamongan. Akademika, 14(1), 111-122.

Nahdi, D. S., \& Jatisunda, M. G. (2020). Analisis Literasi Digital Calon Guru Sd Dalam Pembelajaran Berbasis Virtual Classroom Di Masa Pandemi Covid-19. Jurnal Cakrawala Pendas, 6(2), 116-123. https://doi.org/10.31949/jcp.v6i2.2133

Nordin, M. S., Ahmad, T. B. T., Zubairi, A. M., Ismail, N. A. H., Rahman, A. H. A., Trayek, F. A. A., \& Ibrahim, M. B. (2016). Psychometric Properties of a Digital Citizenship $\begin{array}{llll}\text { Questionnaire. International Education } & \text { Studies, } & 9(3), & \end{array}$ https://doi.org/10.5539/ies.v9n3p71

Putri, A. P., Rahhayu, R. S., Suswandari, M., \& Ningsih, P. A. R. (2021). Strategi Pembelajaran Melalui Daring Dan Luring Selama Daring dan Luring Selama Pandemi Covid-19 di SDN. Sugihan 03 Bendosari. Jurnal Ilmiah Kependidikan, 2(1), 1-8.

Ribble, M. (2012). Digital Citizenship for Educational Change. Kappa Delta Pi Record, 48(4), 148-151. https://doi.org/10.1080/00228958.2012.734015

Ribble, M., \& Bailey, G. (2007). Digital Citizenship in School. In Digital Citizenship in Schools. International Society for Technology in Education.

Rye, S. A. (2013). Learning about distant places through the Internet: Young students as global citizens? Norsk Geografisk Tidsskrift, 67(3), 148-156. https://doi.org/10.1080/00291951.2013.803260

Santika, I. W. E. (2020). Pendidikan Karakter pada Pembelajaran Daring. Indonesian Values and Character Education Journal, 3(1), 8-19.

Trilling, B., \& Fadel, C. (2009). 21st century skills: learning for life in our times. Jossey-Bass.

Triyanto. (2020). Peluang dan tantangan pendidikan karakter di era digital. Jurnal Civics: Media Kajian Kewarganegaraan, 17(2), 175-184. https://doi.org/10.21831/jc.v17i2.35476

Undang-undang 20. (2003). Sistem Pendidikan Nasional.

UNESCO. (2015). Fostering Digital Citizenship through Safe and Responsible Use of ICT: A Review of Current Status in Asia and the Pacific as of December 2014. UNESCO Bangkok, 72.

Young, D. (2014). A 21st-Century Model for Teaching Digital Citizenship. Educational Horizons, 92(3), 9-12. https://doi.org/10.1177/0013175x1409200304 